\title{
In situ research on temperature dependence of the lattice parameters of fusible metals in thin $\mathrm{Cu}-\mathrm{Pb}$ and $\mathrm{Cu}-\mathrm{Bi}$ films
}

\author{
S.V.Dukarov, S.I.Petrushenko, V.N.Sukhov, O.I.Skryl \\ V.Karazin Kharkiv National University, \\ 4 Svobody Sq., 61022 Kharkiv, Ukraine
}

Received December 17, 2015

\begin{abstract}
Results of in situ electron diffraction study on temperature dependence of the lattice parameter of fusible component in $\mathrm{Cu}-\mathrm{Pb}$ and $\mathrm{Cu}-\mathrm{Bi}$ two-layer films are presented. It is found that at the room temperature, the parameters of $\mathrm{Pb}$ and $\mathrm{Bi}$ crystal lattices are agreed with the tabular data, however, with temperature increasing one can observe the deviation from the values corresponding to bulk samples. This indicates a significant increase of solubility of the components in the films under study. In the Cu-Pb films according to the estimation made by assuming a linear dependence of the lattice parameter of the solid solution from concentration, copper solubility in the solid lead at near the eutectic temperature is about 0.8 at. $\%$, which is much greater than the value known for the bulk samples.
\end{abstract}

Keywords: thin films, solubility, lattice parameter.

Представлены результаты in situ электронографического исследования температурной зависимости параметра решетки легкоплавкого компонента в двухслойных пленках $\mathrm{Cu}-\mathrm{Pb}$ и $\mathrm{Cu}-\mathrm{Bi}$. Обнаружено, что при комнатной температуре параметры кристаллических решеток $\mathrm{Pb}$ и Ві согласуются с табличными данными, однако, с ростом температуры наблюдается их отклонение от значений, соответствующих массивным образцам. Это свидетельствует о возрастании растворимости компонентов в исследованных пленках. В пленках $\mathrm{Cu}-\mathrm{Pb}$ согласно оценке, выполненной в предположении линейной зависимости параметра решетки твердого раствора от концентрации, растворимость меди в твердом свинце вблизи температуры эвтектики составляет около 0.8 ат.\%, что на порядок больше значения, известного для массивных образцов.

In situ дослідження температурної залежності параметрів граток легкоплавких металів у тонких плівках $\mathrm{Cu}-\mathrm{Pb}$ та $\mathrm{Cu}-\mathrm{Bi}$. С.В.Дукаров, С.І.Петрушенко, В.М.Сухов, O.І.Скриль.

Наведено результати in situ електронографічного дослідження температурної залежності параметра кристалічної гратки легкоплавкого компонента у двошарових плівках $\mathrm{Cu}-\mathrm{Pb}$ та $\mathrm{Cu}-\mathrm{Bi}$. Виявлено, що при кімнатній температурі параметри кристалічних граток $\mathrm{Pb}$ та Вi відповідають табличним значенням, однак, зі зростанням температури спостерігається їх відхилення від значень, що відповідають масивним зразкам. Це свідчить про зростання розчинності компонентів у досліджених плівках. У плівках $\mathrm{Cu} \mathrm{Pb}$ згідно з оцінкою, виконаною у припущенні лінійної залежності параметра кристалічної гратки твердого розчину від концентрації, розчинність міді у твердому свинці поблизу температури евтектики становить близько 0.8 ат.\%, що на порядок більше значення, відомого для масивних зразків. 


\section{Introduction}

Different alloys and composite materials with the size of the structural elements of the order of several nanometers are being increasingly used in modern fields of science and technology. Such materials can have unique structural properties, and also can represent various types of active media (electronic, magnetic, optical, etc.), which are functional elements of the modern devices and equipment. The variety of such objects applications and the possibility to control their properties occur due to various size effects. Thus, in the nanoscale systems one may observe the change of thermodynamic $[1,2]$ and electrophysical [3, 4] characteristics, shift of phase diagrams lines [2,5], existence of the metastable phases $[6,7]$ and others. However, practical use of these processes and phenomena is impossible without a thorough study of the substances properties in the highly dispersed state.

The lattice parameter change studies under influence of various factors allow us to analyze the processes occurring in the sample volume. In particular, such studies can provide information on mutual solubility in two-component system, as during the formation of a solid solution one can observe the regular change of its lattice parameter. For isostructural components the lattice parameter of the solid solution of substitution is a linear function of its composition in the first approximation. This makes it possible to use electron diffraction studies to determine the solubility in thin films.

Mutual solubility of the substances used for producing composite materials or multicomponent thin film products, is an important parameter, which largely determines their stability and durability. So mutual dissolution, along with other mechanisms, such as: growth through pores [8] or diffusion component [9], the intensity of which increases in going to nanometer size [9, 10], may cause degradation and subsequent destruction of the product. The mutual solubility of substances acquires special value for thin films and especially for the thinnest surfactant layers [11], reduction in the thickness and increase of stability of which is one of the key task of the modern electronics.

For samples that are in the massive state, the literature contains extensive experimental material, which includes information about the phase diagrams as a number of contact pairs and their mutual solubility. At the same time, data about the features of solubility in nanoparticles, contacting both with other nanoparticles, and with the massive phase are less significant.

The published experimental and theoretical data suggest that in the transition from massive samples to the nanometer ones, substantial changes such as the value of their mutual solubility and thermal stability characteristics of the resulting solution may occur. The results of $[9,12]$ show a decrease in the temperature of formation of solid solutions in thin $\mathrm{Au}-\mathrm{Ni}$ and $\mathrm{Ag}-\mathrm{Pd}$ films. Also, a substantial increase of solubility in the nanosamples is specified in [13], where the increase of solubility of carbon in $\mathrm{Au}$ nanoparticles of $5 \mathrm{~nm}$ size is found to be more than four orders of magnitude, in comparison with the bulk sample. According to $[14,15]$, this situation can occur for the contact pairs with the low solubility in the massive state. A perspective in situ method of studying of solubility in thin films is proposed in [10]. The authors found, that dissolution of $\mathrm{Ge}$ in $\mathrm{Ag}$ causes a change in the resistance film system that can be used to study the solubility in thin films.

Theoretically, the effect of size on solubility of contacting phases was studied in $[16,17]$. Although the authors use different approaches, the overall result of these works is the conclusion about possibility of growth of the solubility and change of the lines position on the phase diagram in the transition from bulk samples to highly dispersive ones. This opens up opportunities for creation of various nanocomposite materials with unique properties.

It is worth noting that such materials, in which nanoparticles of the substance in contact with the solid phase of the other one, are widely used in the modern technology. Thus, the system of "nanoparticles in solid matrix" is an important object of modern electronics, and doping substances by nanoscale inclusions is a well known method of controlling the materials properties. Therefore, the study of such systems is not purely scientific but also of great practical importance.

\section{Experimental}

Thin $\mathrm{Cu}-\mathrm{Pb}$ and $\mathrm{Cu}-\mathrm{Bi}$ film systems, in which at least one phase is in the highly dispersed state were selected for the study. According to [18] the components of these systems constitute a phase diagram of eutectic type with the eutectic point located very close to the fusible component (0.2 at\% $\mathrm{Cu})$ and its melting temperature. 
The selected systems are characterized by a very low solubility of the components in the solid state. Thus, up to the eutectic temperature, the solubility of $\mathrm{Cu}$ in $\mathrm{Pb}$ does not exceed 0.023 at. $\%$. In the literature there are almost no data of $\mathrm{Cu}$ solubility in solid $\mathrm{Bi}$ and it is expected to be negligibly small [19]. The solubility of the fusible metals in $\mathrm{Cu}$ at temperature of $600^{\circ} \mathrm{C}$, is less than 0.09 at. $\%$ for lead and about 0.0003 at $\%$ for bismuth. In accordance with [14, 15] for such systems it is possible to observe an increase in solubility in the dispersed state.

When one select objects of study it is also taken into account that for these film systems phase transitions were previously investigated by measuring the temperature dependence of resistivity [20]. Thus, in particular, the following has been found. When first heated, the resistance of pure copper films deposited on amorphous carbon at the room temperature irreversibly decreases starting from temperature of about $100^{\circ} \mathrm{C}$. It is accompanied by the lines narrowing in the electron diffraction pattern, which is a clear indication of annealing initially defective structure of the condensate. In subsequent cycles of heating-cooling electrical resistance of the solid copper films with a thickness of $50 \mathrm{~nm}$ is changed reversibly and shows the behavior typical for metals, i.e. it increases linearly with temperature and has no singularities. Such films lose continuity at temperatures above $500^{\circ} \mathrm{C}$. However, the deposition on the continuous copper film, even small amount of lead (about 1 wt.\%) drastically reduces its thermal stability. These samples break even when heated to the melting point of lead, as evidenced by sharp increase in their resistance [20]. Decomposition of the continuous films into the island ones is natural and frequent process. For its prevention surfactant ultrathin layers improving the interaction of the film and the substrate are commonly used $[11,21]$. However, these phenomena are typical for thinner layers than those used in this paper. A mutual dissolution of the components, which occurs mainly at grain boundaries [22], which are the main defects in polycrystalline films can probably an important role in the decay of relatively thick $\mathrm{Cu}-\mathrm{Pb}$ films into island ones. These processes facilitate the mass transfer in $\mathrm{Cu}$ films, for which island state on the amorphous carbon substrate is energetically more favorable than continuous. The rate of thermal decomposition of the copper films with admixture of lead increases compared to the films of pure copper. High activity of the thermal decomposition may indicate that the mutual solubility in this system which is negligible in the massive state is much greater in the studied films.

Samples for the study were multi-layered films composed of two layers of studied components and additional carbon layers. The films were obtained by successive condensation in vacuum $10^{-6}-10^{-7} \mathrm{~mm} \mathrm{Hg}$ on fresh cleavage of $\mathrm{KCl}$ single crystals with pre-deposited sublayer of amorphous carbon with the thickness of about $20 \mathrm{~nm}$. The carbon film prevented interaction of the components of the system under study with the substrate and ensures the integrity of the sample while separating it from the substrate for electron diffraction studies. Carbon was deposited from a voltaic arc, and metals under study were deposited by thermal evaporation from molybdenum boats, heated by direct passage of electric current. The metal layer thickness was measured during their deposition using a quartz oscillator and it was $10^{-20} \mathrm{~nm}$ in different experiments.

After completion of the condensation of the studied film system in order to protect it from the effects of atmospheric gases, the amorphous carbon layer was also deposited on the film surface. The system of mobile shields used in a vacuum chamber allowed in one experiment, i.e., under the same conditions, to obtain two sets of the samples: $\mathrm{Cu}-\mathrm{Pb}$ (or $\mathrm{Cu}-\mathrm{Bi}$ ) films, as a subject of the study and $\mathrm{Cu}-\mathrm{C}-\mathrm{Pb}$ test samples, where between copper and lead there was an intermediate layer of amorphous carbon with the thickness 20-30 $\mathrm{nm}$ in order to prevent their interaction. Necessity of the test samples application is due to the fact that along with change of the lattice parameters elements related to their mutual solubility with increasing temperature in the samples, one can observe increase of the lattice parameters due to thermal expansion. In addition, the control samples were used for taking into account any possible size dependence [2] of the lattice parameters of the system components.

The resulting samples were removed from the vacuum chamber and were placed on a copper mesh for electron microscopy. Electron microscopic studies were carried out by transmission electron microscope Selmi PEM 125K, and electron diffraction ones using electron microscope Selmi EMV100BR, equipped with the original device for in situ electron diffraction studies of 

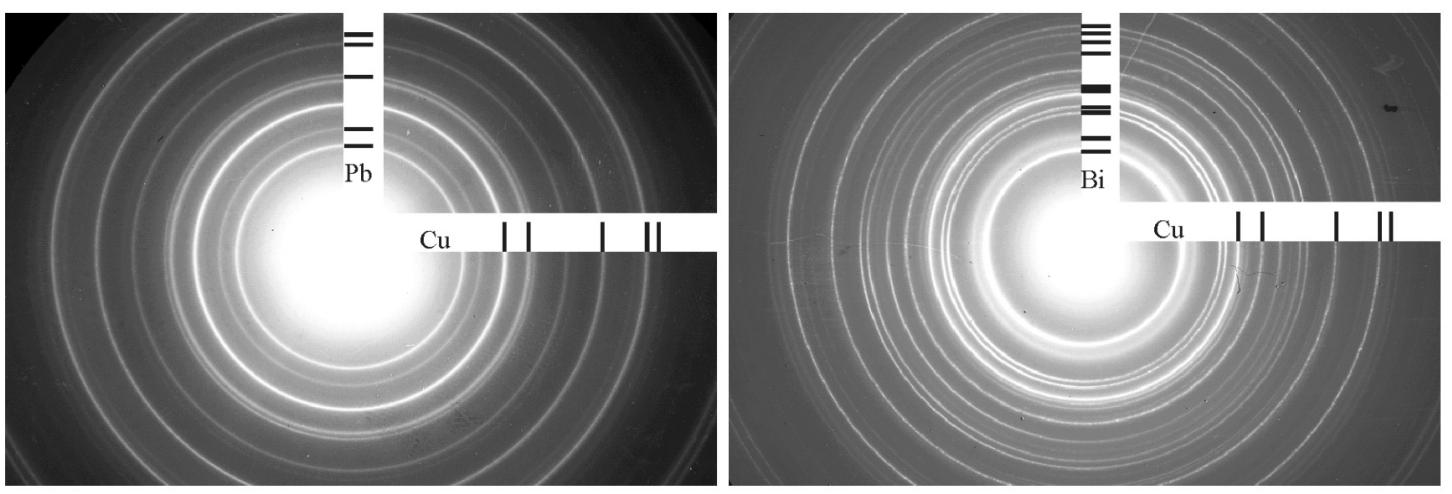

Fig. 1. Electron diffraction pattern of bilayer $\mathrm{Cu}-\mathrm{Pb}$ and $\mathrm{Cu}-\mathrm{Bi}$ films.
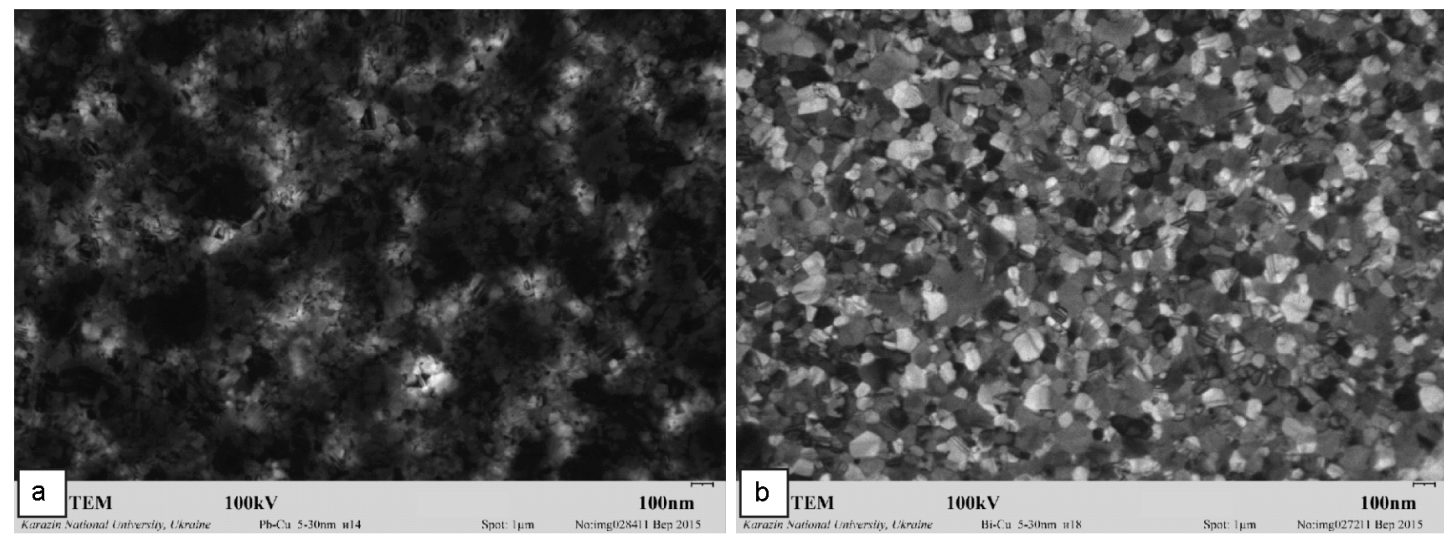

Fig. 2. TEM images of $\mathrm{Cu}-\mathrm{Pb}$ (a) and $\mathrm{Cu}-\mathrm{Bi}$ (b) films.

the samples when heating and cooling. The device was a massive (compared to electronmicroscopic mesh) resistive heating unit, which the sample was placed into. The unit temperature was measured by using a thermocouple of K-type welded to it directly in the place of the sample fixing. Calibration of the device on melting temperatures of fusible metals showed that the mesh temperature differs from the temperature of the heating unit in which it is fixed, not more than $5 \mathrm{~K}$.

The samples were subjected to a series of cycles of heating - cooling with periodical shooting electron diffraction patterns corresponding to different temperatures. Obtained electron diffraction patterns (Fig. 1) were used to determine the temperature dependence of the lattice parameters of the components of the tested contact pairs. As one can see in Fig. 1 due to the significant difference in the lattice parameters, the system of reflexes that correspond to copper and fusible elements, are clearly separated. To ensure in the film a full flow of diffusion processes responsible for the dissolution, before shooting electronograms the samples were kept at a given temperature for an hour.

\section{Results and discussion}

Fig. 2 shows electron micrographs of $\mathrm{Cu}-$ $\mathrm{Pb}$ and $\mathrm{Cu}-\mathrm{Bi}$ films, obtained by condensation on a substrate at the room temperature, after heating to the melting temperature of the fusible component. Unlike metal condensates on an oxide or carbon substrate upon which the fusible component tends to gather in the spherical particles [23-25], in this case, due to the good wetting typical for systems such as metal-metal [2], the fusible component is in a copper film in the form of shapeless inclusions. As it can be seen in Fig. 2, characteristic size of the structural units is equal to dozens of nanometers, which makes it possible to display size effects in the films under study.

As a result of the performed electrographic research it was found that the investigated $\mathrm{Cu}-\mathrm{Pb}$ films and control samples, in which layers of copper and lead were separated with a sufficiently thick carbon film, behave differently while heating. Fig. 3 shows the results of measurement of the lattice parameters of lead and copper in the layered $\mathrm{Cu}-\mathrm{Pb}$ and $\mathrm{Cu}-\mathrm{C}-\mathrm{Pb}$ films (blackened and light-colored dots, respectively). One can see that in the studied 


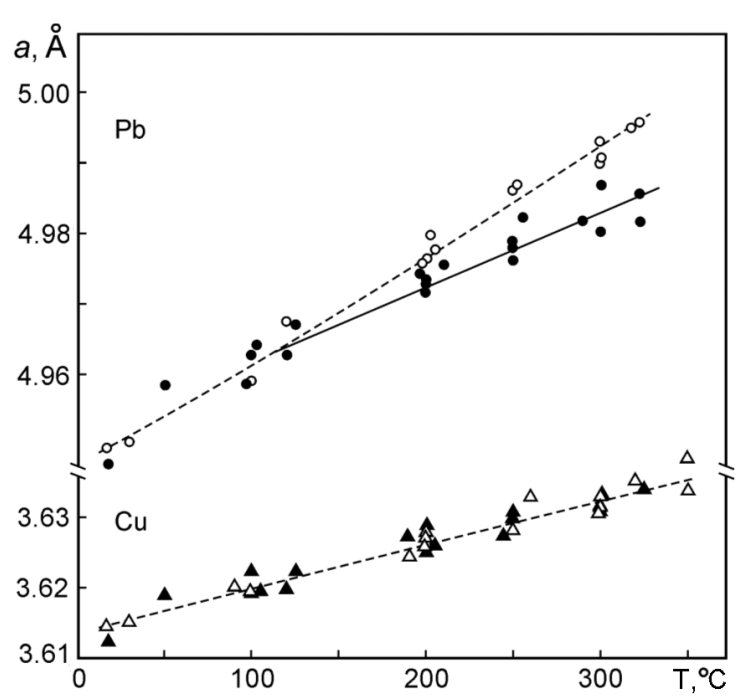

Fig. 3. Temperature dependences of the lattice parameters of copper and lead in $\mathrm{Cu}-\mathrm{C}-\mathrm{Pb}$ $(\Delta, 0)$ and $\mathrm{Cu}-\mathrm{Pb}(\boldsymbol{\Delta}, \bullet)$ films. Dashed lines correspond to the thermal expansion for massive samples.

temperature range mostly there are no systematic deviations of the measured values of the lattice parameters of copper and lead from the table values (dashed lines) for the control samples and their changes with temperature within the measurement error correspond to the published data for the bulk. The obtained data also indicate a lack of size dependence of the lattice parameter.

When studying the film in which copper and lead are in direct contact, it was found that up to the temperature of $120^{\circ} \mathrm{C}$ lattice parameters of the components in the studied $\mathrm{Cu}-\mathrm{Pb}$ samples and $\mathrm{Cu}-\mathrm{C}-\mathrm{Pb}$ control samples at appropriate temperatures are almost identical (Fig. 3). This indicates that the solubility in these films up to this temperature is below a limit which can be reliably observed, using the above mentioned technique. However, starting from temperature of about $120^{\circ} \mathrm{C}$, the lattice parameters of lead in $\mathrm{Cu}-\mathrm{Pb}$ films and $\mathrm{Cu}-\mathrm{C}-\mathrm{Pb}$ control samples are different. As it can be seen in Fig. 3, there is distinct systematic deviation from the dashed line corresponding to the published data for the bulk samples on the dependence $a(T)$ for lead in the $\mathrm{Cu}-\mathrm{Pb}$ films. Thus, a visible decrease in the lattice parameter of lead as compared with the calculated value for a given temperature occurs in the $\mathrm{Cu}-\mathrm{Pb}$ samples. Since the copper lattice parameter is smaller than that of lead, such a behavior should be observed during formation of the solid solution.

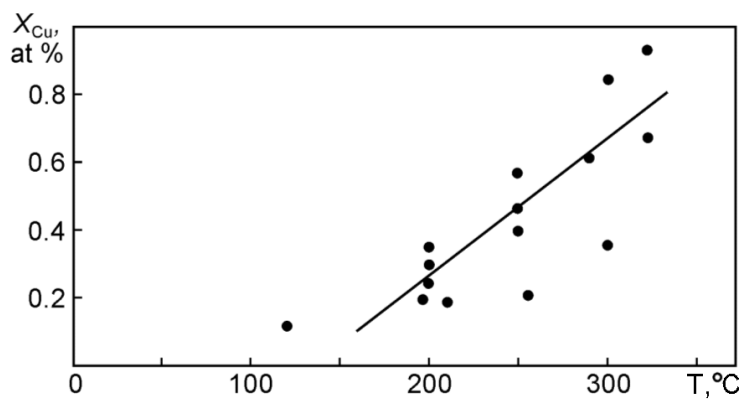

Fig. 4. Copper solubility in solid lead versus temperature in $\mathrm{Cu}-\mathrm{Pb}$ films.

To quantify solubility in the first approximation we assume that for substances with the same crystal structure the lattice parameter of the two-component solution changes linearly with the components concentration. To calculate the concentration of copper the experimental data on the lattice parameters of lead in $\mathrm{Cu}-\mathrm{Pb}$ films and lattice parameters of the pure components in accordance with the data on thermal expansion of the bulk samples were used. Calculated in such a way dependence of the copper solubility in lead from the sample temperature is shown in Fig. 4. It can be seen that the $\mathrm{Cu}-\mathrm{Pb}$ films solubility increases with the rise of temperature and at about the melting point of lead reaches 0.8 at. $\%$. This value is more than an order greater than that of limiting solubility of copper in solid lead in the bulk state known from the literature [18].

It should be noted that since, according to the phase diagram, the eutectic point for the bulk samples is observed at the much lower concentration of $\mathrm{Cu}(0.18$ at. $\%)$, the obtained increase in solubility in the thin $\mathrm{Cu}-\mathrm{Pb}$ film system must be accompanied by shift of the point of eutectic equilibrium towards the higher concentration of copper.

The temperature dependence of the bismuth lattice parameter in thin $\mathrm{Cu}-\mathrm{Bi}$ films also showed its distinctive reduction in comparison with the value that must be occurred taking into account the thermal expansion (Fig. 5).

The found deviation may be caused, as well as in the $\mathrm{Cu}-\mathrm{Pb}$ system, with the dissolution of copper in the solid bismuth. As copper and bismuth have different crystal structures it will not be right to apply directly to this system the assumption of a linear dependence of concentration of the solid solution from changing its lattice parameters. It is worth noting that the reduction of the lattice parameter of bismuth can 


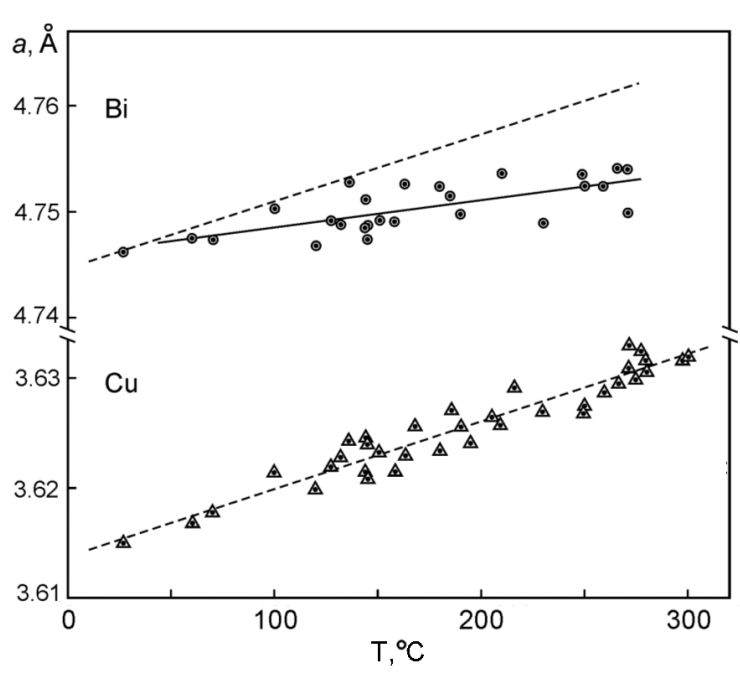

Fig. 5. Temperature dependences of copper and bismuth lattice parameters in $\mathrm{Cu}-\mathrm{Bi}$ films. Dashed lines are drawn in accordance with the published data for massive samples.

be expected while dissolving in it smaller copper atoms in the case of substitutional solid solution is formed. In spite of the differences in the crystal structures of the pure components, in the case of low concentrations, the atoms of the solute substance are arranged in the crystal lattice sites of the solvent. Accordingly, in the first approximation, we can estimate the concentration of the solution, as well as for the above-discussed $\mathrm{Pb}-\mathrm{Cu}$ system, using the corresponding atomic radii instead of the lattice parameters. The estimation of copper concentration in the solid bismuth near the eutectic temperature gives the value of 0.9 at. $\%$, which can no longer be considered "negligibly small" [19] and exceed the value of the eutectic concentration known from the literature [18].

\section{Conclusions}

Increase of copper solubility in thin $\mathrm{Cu}-$ $\mathrm{Pb}$ and $\mathrm{Cu}-\mathrm{Bi}$ films has been found out. Temperature dependence of the limiting solubility of copper in the condensed films of lead has been obtained. In assumption of the constant type of a the phase diagram during transition to the nanoscale samples it has been shown that in the studied binary alloys the eutectic point of equilibrium is shifted in the direction of the greater copper concentration.

\section{References}

1. A.I.Gusev, Nanomaterials, Nanostructures, Nanotechnologies, Fizmatlit, Moscow (2005) [in Russian].

2. N.T.Gladkikh, S.V.Dukarov, A.P.Kryshtal et al., Surface Phenomena and Phase Transitions in Condensed Films, V.Karazin Kharkiv National University, Kharkiv (2004) [in Russian].

3. R.I.Bigun, O.E.Kravchenko, Z.V.Stasyuk, D.S.Leonov, Metallofiz. Noveishie Tekhn., 34, 301 (2012).

4. L.Odnodvorets, S.Protsenko, O.Synashenko et al., Cryst. Res. Technol., 44, 74 (2009).

5. N.T.Gladkikh, A.P.Kryshtal, R.V.Sukhov, Phys. Solid State, 52, 585 (2010).

6. N.T.Gladkikh, S.V.Dukarov, V.N.Sukhov, $Z$. Metallkunde, 87, 233 (1996).

7. N.T.Gladkikh, S.V.Dukarov, V.N.Sukhov, I.G.Churilov, Functional Materials, 18, 529 (2011).

8. S.V.Dukarov, S.I.Petrushenko, V.N.Sukhov, I.G.Churilov, Probl.Atom.Sci.Technol., 1, 110 (2014).

9. A.P.Kryshtal, S.I.Bogatyrenko, R.V.Sukhov, A.A.Minenkov, Appl. Phys. A, 116, 1891 (2014).

10. A.A.Minenkov, S.I.Bogatyrenko, A.P.Kryshtal, J. Nano-Electron. Phys., 6, 04026 (2014).

11. M.Marszalek, A.Polit, V.Tokman et al., Surf. Sci., 601, 4454 (2007).

12. S.I.Bogatyrenko, Techn. Phys., 59, 1374 (2014).

13. E.A.Sutter, W.P.Sutter, J.Mater.Sci., 46, 7090 (2011).

14. A.I.Zubkov, A.I.Il'inskii, O.A.Podgornaya et al., Fizika Metallov i Metallovedenie, 10, 197 (1990).

15. H.Gleiter, J.Weissmuller, O.Wollersheim, R.Wurschum, Acta Mater., 49, 737 (2001).

16. V.M.Koshkin, V.V.Slezov, Techn. Phys. Lett., 30, 38 (2004).

17. A.Mihranyan, M.Stromme, Surf. Sci., 601, 315 (2007).

18. N.P.Lyakishev, Phase Diagrams of Binary Metallic Systems, Mashinostroenie, Moscow (2001) [in Russian].

19. D.J.Chakrabarti, D.E.Laughlin, Bull. Alloy Phase Diagrams, 5, 148 (1984).

20. S.I.Petrushenko, S.V.Dukarov, V.N.Sukhov, Vacuum, 122(A), 208 (2015).

21. R.I.Bigun, O.E.Kravchenko, D.S.Leonov et al., Metallofiz. Noveishie Tekhnol., 35, 603 (2013).

22. A.N.Zhiganov, A.Ya.Kupryazhkin, Techn. Phys., 75, 63 (2005).

23. S.I.Petrushenko, S.V.Dukarov, V.N.Sukhov, I.G.Churilov, J.Nano-Electron.Phys., 7, 02033 (2015).

24. S.V.Dukarov, Thin Solid Films, 323, 136 (1998).

25. N.T.Gladkikh, S.V.Dukarov, V.N.Sukhov, Fiz. Met. Metalloved., 78, 87 (1994). 